\title{
PENGARUH PREKUENSI SOSIALISASI TERHADAP PENERIMAAN PAJAK BUMI DAN BANGUN DI KOTA PALOPO
}

\author{
I Ketut Patra ${ }^{1}$, Hadrah $^{2}$, Ismawati $^{3}$ \\ 1) Dosen Sekolah Tinggi Ilmu Ekonomi Muhammadiyah Palopo \\ ${ }^{2,3)}$ Dosen Sekolah Tinggi Ilmu Ekonomi Muhammadiyah Palopo
}

\begin{abstract}
Abstrak:Rumusan masalah dalam penelitian adalah apakah frekuensi sosialisasi berpengaruh terhadap penerimaan pajak bumi dan bangunan di kota palopo. Yang menjadi tujuan penelitian adalah Untuk mengetahui apakah frekuensi sosialisasi berpengaruh terhadap Penerimaan Pajak Bumi dan Bangunan di kota palopo.

Berdasarkan hasil penelitian dan pembahasaan dari variable frekuensi sosialisasi sesuai dengan hasil yang di peroleh menjelaskan bahwa tidak memiliki pengaruh terhadap Pajak Bumidan Bangunan di Kota Palopo.Hasil nilai koefisien regresi adalah -227,574,220 artinya setiap terjadi penurunan jumlah frekuensi sosialisasi Pajak Bumi dan Bangunan Kota Palopo berdampak terhadap penerimaan Pajak Bumi dan Bangunan sebesar Rp 227,574,220. Dari hasil analisis data dengan menggunakan Model Summary di atas,di ketahui bahwa nilai $R$ (koefisien korelasi) sebesar 0,442\% atau 44,2\%,memberikan arti bahwa hubungan yang lemah antara independen variable (penerimaan Pajak Bumi dan Bangunan) sebesar 0,442\% atau 44,2\% artinya bahwa hubungan secara parsial karena 0,442 sangat jauh dari angka 1. Hasil nilai Adjusted $R$ Square =0,081 memberikan arti bahwa factor yang mempengaruhi penerimaan Pajak Bumi dan Bangunan Kota Palopo yaitu frekuensi sosialisasi (X) yang memberikan sumbangan sebesar 0,081\% atau 8,1\% di mana sisanya 91,9\% sangat di pengaruhi oleh variable lain di luar modal.
\end{abstract}

Kata Kunci: Frekuensi sosialisasi dan Penerimaan Pajak Bumi dan Bangunan

\section{PENDAHULUAN}

Pajak dikategorikan pengelolaanya menjadi Pajak yang dikelola Pemerintah Pusat dan Pajak yang dikelola Pemerintah Daerah. Salah satu pajak yang dikelola oleh Pemerintah Pusat dan hasilnya didistribusikan kepada Pemerintah Daerah adalah Pajak Bumi dan Bangunan (PBB). PBB merupakan satu-satunya pajak properti di Indonesia sebagaimana tertulis dalam undangundang Nomor 12 tahun 1994. PBB sebagai pajak obyektif, yaitu pajak negara yang sebagaian besar penerimanya merupakan pendapatan daerah yang antara lain dipergunakan untuk penyediaan fasilitas yang juga dinikmati oleh Pemerintah Pusat maupun Pemerintah Daerah. Oleh sebab itu, wajar bila pemerintah pusat juga ikut membiayai penyediaan fasilitas tersebut melalui pembayaran Pajak Bumi dan Bangunan (PBB). Pajak Bumi dan Bangunan (PBB) termasuk sumber keuangan negara dan pemungutannya sudah didasarkan undang-undang, ini berarti bahwa pemungutan pajak sudah disepakati bersama antara pemerintah dengan masyarakat. Pajak sebagai salah satu sumber Pemerintah dalam negeri merupakan sektor potensial, penerimaan sektor pajak ini selanjutnya dimanfaatkan oleh Pemerintah untuk membangun sarana dan prasarana kepentingan umum. Mengingat betapa pentingnya peran masyarakat dalam peran sertanya menanggung pembiayaan negara, maka dituntut adanya kesadaran masyarakat untuk membayar PBB dengan benar sesuai dengan peraturan perundangundangan yang berlaku. Namun kenyataannya, banyak hambatan yang dihadapi dalam pemungutannya. Hal ini disebabkan karena kurangnya kesadaran masyarakat atau bahkan tidak mengerti pajak, sehingga masyarakat tidak 
melaksanakan kewajibannya dalam membayar pajak. Tidak sedikit ahli berpendapat bahwa pada umumnya manusia tidak suka membayar pajak. Dikatakan bahwa hanya sekelompok kecil orang yang merasakan pajak tidak memberatkan mereka. Mereka merasa membayar pajak terlalu sedikit jika dibandingkan dengan jumlah yang seharusnya dia bayar. Di Propinsi, majalah tempo tahun 2004 pernah melakukan penelitian tentang sikap membayar pajak. Dari 991 responden yang diwawancarai, $8,89 \%$ diantaranya menyatakan bahwa mereka, membayar pajak dalam jumlah yang kecil. Hasil survei yang dilakukan di beberapa daerah di Sulawesi Selatan (Pinrang, Sidrap dan Pangkep) menunjukkan bahwa orang tidak selalu mengharapkan pajaknya diturunkan seperti yang sering diduga banyak orang. Penelitian yang dilakukan oleh (Arman,2013) ditemukan bahwa persentase orang yang bersedia pajaknya dinaikkan, bila pelayanan terhadap masyarakat ditingkatkan, jauh lebih besar dari persentase orang yang minta pajaknya diturunkan (Ancok, 2004:1). Gambaran di atas, sekilas terkesan bahwa orang tidak selalu anti dengan pajak. Meski demikian ada pula indikasi semakin berkurangnya toleransi orang pada pajak. Penelitian jangka panjang di lakukan pemerintah memperlihatkan munculnya kecenderungan orang semakin antipati pada pajak. Di tahun 2004 terdapat $61 \%$ responden Gallup Pool menjawab bahwa pajak yang mereka bayar terlalu tinggi.

Pembangunan nasional dapat dilaksanakan apabila ada dana yang tersedia. Dana tersebut dapat diperoleh dari berbagai sumber baik dari dalam maupun luar negeri, baik sektor swasta maupun pemerintah. Salah satu sumber penerimaan dalam negeri adalah dari sektor pajak. Pajak merupakan sumber utama penerimaan negara yang bertujuan untuk meningkatkan kesejahteraan rakyat dengan cara meningkatkan pelayanan publik (Soemitro , 2010 dalam Sulistyono, 2012). Penerimaan pendapatan yang berasal dari sektor pajak terdiri atas $\mathrm{PPh}$ Non Migas (PPh pasal 21, 22, 23, 25, 29, 26, PPh final dan $\mathrm{PPh}$ nonmigas lainnya), PPh Migas, PPn dan PPnBM, PBB, Pajak lainnya. PPh nonmigas merupakan salah satu jenis sumber penerimaan pajak yang terbesar.Untuk itu jenis penerimaan pendapatan dari sektor pajak ini setiap tahun anggaran diupayakan mengalami kenaikan. Namun keinginan yang diharapkan tidak sejalan dengan apa yang diharapkan. Pada tahun $2012 \mathrm{PPh}$ nonmigas-nonmigas mengalami perlambatan pertumbuhan dari Palopo, Propinsi Sulawesi Selatan dalam pembangunannya sangat ditentukan oleh ketersediaan dana yang dimiliki, dimana dana tersebut diperoleh dari berbagai sumber pendapatan, baik Pendapatan Asli Daerah (PAD) itu sendiri maupun subsidi dari pemerintah pusat, sejauh ini Pendapatan Asli Daerah (PAD) yang diperoleh masih dalam jumlah yang kecil yang mengakibatkan pembangunan yang dilaksanakan belum berjalan dengan baik. Oleh sebab itu, anggaran pembangunan Kota Palopo sangat memerlukan perhatian dan pemikiran yang sungguh-sungguh sehingga kedepannya dapat dilaksanakan secara berkesinambungan.

Mengingat bahwa tidak semua pembiayaan pembangunan dapat diberikan oleh pemerintah pusat kepada daerah, maka daerah dituntut untuk meningkatkan potensi-potensi keuangannya sendiri berdasarkan peraturan perundang- 
undangan yang berlaku. Salah satu diantaranya adalah peningkatan penerimaan dari Pajak Bumi dan Bangunan. Pajak Bumi dan Bangunan (PBB) yang ada di Kota Palopo Sulawesi Selatan dipungut berdasarkan Undang-Undang No. 12 Tahun 1985 sebagaimana telah diubah dengan Undang-Undang No. 12 Tahun 1994 tentang Pajak Bumi dan Bangunan. Undang-Undang ini bertujuan menegakkan kemandirian dama a + membiayai pembangunan dengan mewujưdkan keikutsertaan dan kegotongroyongan selbôn lapisan masyarakat.

Dengan adanya Undang-Undang tersebut, selama ini sudah dapat memberikan dalmpalk b positif terhadap peningkatan Pendapatan eAsli Daerah di Kota Palopo Sulawesi Selatan Peningkatan terjadi karena semakin diintensifkannya pemungutan dan bertambahnya jumlah objek Pajak Bumi dan Bangunan. Pemerintah Daerah telah memanfaatkannya melalui perluasan kegiatan pembangunan setiap tahun walaupun belum secara optimal.

\section{BAHAN DAN METODE}

Metode pengumpulan data yang digunakan penulis dalam penelitian ini adalah Observasi partisipatif, Interview (wawancara), Kepustakaan. Populasi dalam penelitian ini adalah seluruh kecamatan yang ada di Kota Palopo yang berjumlah 9 Kecamatan yang sekaligus dijadikan sebagai sampel penelitian.

Jenis data yang digunakan yaitu data kuanlitatif dan kuantitatif, sedangkan sumber datanya data primer dan sekunder.
Untuk melakukan analisis secara statiistik terhadap temuan yang diperoleh melalui hasil penelitian ini digunakan pengaruh regresi linear sederhana yaitu salah bentuk analisis yang digunakan untuk mengetahui pengaruh Frekuensi sosialisasi terhadap Pendapatan di Kota Palopo dengan rumus menurut Sugiyono (2010:114) sebagai Berikut:

$\mathrm{b} X+\mathrm{ei}$

$=$ Penerimaan Pajak Bumi dan Bangunan

$=$ Konstanta

= Frekuensi Sosialisasi Wajib Pajak Bumi Dan Bangunan

= Koefisien Regresi dari Variabel X (Parameter)

$=$ Variabel pengganggu

\section{HASIL DAN PEMBAHASAN}

\section{Frekuensi Sosialisasi Pajak Bumi dan Bangunan di Kota Palopo}

Pemerintah Kota Palopo harus lebih giat mensosialisasikan kepada masyarakat untuk taat membayar pajak. Dalam setahun Pemerintah Kota Palopo melalui setiap Sembilan Kecamatan yang ada di Kota Palopo selalu melakukan kegiatan sosialisasi pajak. Adapun Frekuesnsi sosialisasi Pajak Bumi dan Bangunan yang dilakukan oleh Pemerintah Kota Palopo dalam setahun untuk lima tahun terakhir yaitu dari tahun 2010 - 2014 dapat kita lihat pada tabel di bawah ini: 
Tabel Frekuensi Sosialisasi Pajak

\begin{tabular}{|c|c|c|c|c|c|c|c|c|c|c|c|}
\hline \multirow{2}{*}{$\begin{array}{c}\text { N } \\
\text { o }\end{array}$} & Th & Wara & $\begin{array}{c}\text { Wara } \\
\text { Utar } \\
\text { a }\end{array}$ & $\begin{array}{c}\text { Wara } \\
\text { Selatan }\end{array}$ & $\begin{array}{c}\text { Wara } \\
\text { Timu } \\
\mathrm{r}\end{array}$ & $\begin{array}{c}\text { Wara } \\
\text { Barat }\end{array}$ & Sendana & $\begin{array}{c}\text { Mungkajan } \\
\text { g }\end{array}$ & Bara & $\begin{array}{c}\text { Teliwanu } \\
\text { a }\end{array}$ & Jmh \\
\hline 1 & 2010 & 3 & 3 & 2 & 3 & 2 & 4 & 4 & 3 & 3 & 30 \\
\hline 2 & 2011 & 2 & 2 & 2 & 2 & 3 & 3 & 3 & 2 & 2 & 21 \\
\hline 3 & 2012 & 4 & 3 & 3 & 3 & 3 & 3 & 4 & 4 & 4 & 31 \\
\hline 4 & 2013 & 3 & 3 & 3 & 3 & 3 & 3 & 3 & 3 & 3 & 27 \\
\hline 5 & 2014 & 2 & 3 & 4 & 4 & 4 & 3 & 3 & 3 & 3 & 29 \\
\hline
\end{tabular}

Berdasarkan data pada tabel di atas dapat kita ketahui bahwa Pemerintah Kota Palopo selalu melakukan sosialisasi pajak setiap tahun di setiap Kecamatan yang ada di Kota Palopo. Pada tahun 2010 frekuensi sosialisasi di lakukan sebanyak 30 kali, tahun 2011 sebanyak 21 kali, tahun 2012 sebanyak 31 kali, tahun 2013 dilakukan sebanyak 27 kali dan pada tahun 2014 dilakukan sebanyak 29 kali di Sembilan Kecamatan yang ada di Kota Palopo.

\section{Target dan Realisasi Penerimaan Pajak Bumi dan Bangunan di Kota Palopo}

Setiap tahun Pemerintah Kota

Palopo selalu memiliki target yang harus dicapai dari penerimaan Pajak Bumi dan Bangunan. Adapun target dan realisasi penerimaan Pajak Bumi dan Bangunan Kota Palopo dari tahun 2010 - 2014 dapat kita lihat pada tabel 4.2 di bawah ini:

Target dan Realisasi Penerimaan Pajak Bumi dan Bangunan Kota Palopo Tahun 2010 2014

\begin{tabular}{|c|c|c|c|c|}
\hline No & Tahun & Target PBB & Realisasi PBB & Persentase \% \\
\hline 1 & 2010 & 2.001 .630 .173 & 1.524 .120 .513 & 76.15 \\
\hline 2 & 2011 & 1.917 .695 .500 & 1.563 .007 .845 & 81.50 \\
\hline 3 & 2012 & .2 .172 .980 .242 & 1.695 .640 .637 & $78,03 \%$ \\
\hline 4 & 2013 & .2 .317 .735 .436 & 1.875 .868 .499 & $80,94 \%$ \\
\hline 5 & 2014 & 3.662 .661 .167 & .3 .049 .985 .739 & $83,27 \%$ \\
\hline
\end{tabular}


Berdarsarkan data pada tabel di atas dapat kita ketahui bahwa pada tahun 2010 target penerimaan PBB Kota Palopo sebesar Rp.1.557.411.343 namun yang terealisasi hanya sebesar Rp. 1.524.120.513 atau sekitar 76,15\%. Pada tahun 2011 target penerimaan PBB Kota Palopo sebesar Rp. 1.563.007.845 namun yang terealisasi hanya sebesar Rp. 2.172.980.242 atau sekitar 81,50\%. Pada tahun 2012 target penerimaan PBB Kota Palopo sebesar Rp.2.172.980.242 namun yang terealisasi hanya sebesar Rp.1.695.640.637 atau sekitar 78,03\%. Pada tahun 2013 target penerimaan PBB Kota Palopo sebesar Rp.2.317.735.436 namun yang terealisasi hanya sebesar Rp.1.875.868.499 atau sekitar 80,94\%. Dan pada tahun 2014 target penerimaan PBB Kota Palopo sebesar Rp.3.662.661.167 namun yang terealisasi hanya sebesar Rp.3.049.985.739 atau sekitar 83,27\%.

Hal ini menunjukan bahwa dari tahun 2010 - 2014 tidak ada realisasi penerimaan Pajak Bumi dan Bangunan yang mencapai target. Realisasi penerimaan PBB yang terbesar terjadi pada tahun 2014 dan realisasi penerimaan PBB yang terendah terjadi pada tahun 2010. Namun pencapaian PBB dari tahun 2010 - 2014 selalu meningkat. berikut adalah tabel di atas Realisasi Penerimaan Pajak Bumi dan Bangunan Per Kecamatan Kota Palopo Tahun 2011 - 2014:

Realisasi Penerimaan Pajak Bumi dan Bangunan Per Kecamatan Kota Palopo Tahun 2011 - 2014

\begin{tabular}{|c|c|c|c|c|c|}
\hline \multirow{2}{*}{ Nama } & \multicolumn{5}{|c|}{ Tahun } \\
\hline Kecamatan & $\mathbf{2 0 1 0}$ & $\mathbf{2 0 1 1}$ & $\mathbf{2 0 1 2}$ & $\mathbf{2 0 1 3}$ & $\mathbf{2 0 1 4}$ \\
\hline Wara & $459,664,113$ & $482,926,667$ & 667.155 .790 & 730.773 .526 & 935.882 .764 \\
\hline W. Utara & $171,603,052$ & 162.853 .640 & 242.337 .544 & 328.604 .067 & 493.704 .145 \\
\hline W.Selatan & $112,078,310$ & $143.826,028$ & 328.883 .380 & 271.681 .741 & 549.910 .456 \\
\hline W. Timur & $325,546,826$ & 307.285 .764 & 413.208 .646 & 426.251 .981 & 640.619 .369 \\
\hline W. Barat & $82,889,426$ & 82.628 .218 & 88.263 .362 & 88.589 .082 & 151.247 .304 \\
\hline Sendana & $46,209,634$ & 47.314 .123 & 49.861 .336 & 49.721 .222 & 113.738 .606 \\
\hline Mungkajang & $65,689,150$ & 64.618 .625 & 68.140 .251 & 68.797 .953 & 134.069 .274 \\
\hline Bara & $152,670,568$ & 137.568 .571 & 160.122 .484 & 198.254 .074 & 305.715 .615$. \\
\hline Telluwanua & $107,769,434$ & 133.986 .209 & 155.007 .449 & 155.061 .790 & 335.873 .634 \\
\hline Jumlah & $\mathbf{1 , 5 2 4 , 1 2 0 , 5 1 3}$ & $\mathbf{1 . 5 6 3 . 0 0 7 . 8 4 5}$ & $\mathbf{1 , 6 9 5 , 6 4 0 , 6 3 7}$ & $\mathbf{1 . 8 7 5 . 8 6 8 . 4 9 9}$ & $\mathbf{. 3 . 0 4 9 . 9 8 5 . 7 3 9}$ \\
\hline
\end{tabular}




\section{Hasil Penelitian}

\section{Uji regresi linear sederhana}

Untuk mengetahui pengaruh frekuensi sosialisasi terhadap penerimaan Pajak Bumi dan Bangunan di Kota Palopo dalam penelitian menggunakan metode analisis regresi linear sederhana. Adapun data olahan dengan menggunakan program SPSS sebagai berikut:

\section{Tabel Variabel X dan Y}

\begin{tabular}{|l|c|c|}
\hline KECAMATAN & $\begin{array}{c}\mathrm{X} \\
(\text { Kali })\end{array}$ & $\begin{array}{c}\text { PBB }(\mathrm{Y}) \\
(\mathrm{Rp})\end{array}$ \\
\hline WARA & 14 & $3.276,402,860$ \\
\hline WARA UTARA & 11 & $1.399,102,448$ \\
\hline WARA SELATAN & 14 & $1.406,379,915$ \\
\hline WARA TIMUR & 15 & $2.112,912,586$ \\
\hline WARA BARAT & 15 & $493,617,392$ \\
\hline SENDANA & 16 & $306,844,921$ \\
\hline MUNGKAJANG & 18 & $401,315,253$ \\
\hline BARA & 15 & $954,331,312$ \\
\hline TELLU WANUA & 15 & $887,698,516$ \\
\hline
\end{tabular}

Berikut adalah hasil analisis regresi sederhana yang ditransformasikan dengan rumus sebagai berikut:

$\mathrm{Y}=\mathrm{a}+\mathrm{bX}+\mathrm{ei}$

$\mathrm{Y}=$ Penerimaan Pajak Bumi dan Bangunan

$\mathrm{b}^{0} \quad=$ Konstanta

$\mathrm{X}=$ Frekuensi Sosialisasi Wajib Pajak Bumi Dan Bangunan

$\mathrm{a}$ dan $\mathrm{b}=$ Koefisien Regresi dari Variabel $\mathrm{X}$ (Parameter)

ei $\quad=$ Variabel pengganggu

Tabel Coefficients ${ }^{\mathrm{a}}$

\begin{tabular}{|c|c|c|c|c|c|c|}
\hline \multirow{2}{*}{\multicolumn{2}{|c|}{ Model }} & \multicolumn{2}{|c|}{ Unstandardized Coefficients } & \multirow{2}{*}{$\begin{array}{c}\begin{array}{c}\text { Standardized } \\
\text { Coefficients }\end{array} \\
\text { Beta } \\
\end{array}$} & \multirow[b]{2}{*}{$\mathrm{t}$} & \multirow[b]{2}{*}{ Sig. } \\
\hline & & B & Std. Error & & & \\
\hline & (Constant) & 4611775164 & 2596202248 & & 1.776 & 119 \\
\hline & (X) & -227574220.1 & 174464121.1 & -.442 & -1.304 & .233 \\
\hline
\end{tabular}

a. Dependent Variable: pajak bumi dan bangunan

Dari output data pada tabel di atas dapat diperoleh persamaan regresi linear sederhana sebagai berikut:

$\mathrm{Y}=4.611,775,164-227,574,220$

Dari persamaan regresi linear sederhana di atas, dapat diketahui bahwa:

a. Nilai a (Konstanta) adalah 4.611,775,164 artinya apabila variabel frekuensi sosialisasi pada objek Pajak Bumi dan Bangunan di Kota Palopo adalah konstan atau sama dengan nol (0), maka besarnya penerimaan Pajak Bumi dan Bangunan Kota Palopo adalah sebesar Rp $4.611,775,164$ b. Besarnya nilai koefisien regresi (b) adalah 227,574,220 artinya setiap terjadi penurunan jumlah frekuensi sosialisasi Pajak Bumi dan Bangunan Kota Palopo berdampak terhadap penurunan penerimaan Pajak Bumi dan Bangunan sebesar Rp -227,574,220.

c. Analisis koefisien determinasi digunakan untuk mengetahui seberapa besar persentase pengaruh frekuensi sosialisasi terhadap penerimaan Pajak Bumi dan Bangunan di Kota Palopo. 
Tabel Model Summary

\begin{tabular}{|c|c|c|c|}
\hline Model & $\mathrm{R}$ & R Square & Adjusted R Square \\
\hline 1 & .442 & .196 & .081 \\
\hline
\end{tabular}

Berdardasarkan hasil analisis data dari output data pada tabel Model Summary di atas, diketahui bahwa nilai $\mathrm{R}$ (koefisien korelasi) sebesar $0,442 \%$ atau $44,2 \%$, memberikan arti bahwa hubungan yang lemah antara independen variabel (frekuensi sosialisasi) dengan dependen variabel (penerimaan Pajak Bumi dan Bangunan) sebesar $0,442 \%$ atau $44,2 \%$, secara kualitatif, hubungan secara parsial karena 0,442 sangat jauh dari angka 1 untuk melihat pengaruh independen terhadap variabel dependen digunakan Adjusted $\mathrm{R}$ Square $=0,081$ memberikan arti bahwa faktor yang mempengaruhi penerimaan Pajak Bumi dan Bangunan Kota Palopo yaitu frekuensi sosialisasi (X) yang memberikan sumbangan sebesar 0,081\% atau $8,1 \%$ di mana sisanya $91,9 \%$ sangat di pengaruhi oleh variabel lain di luar modal.

\section{Uji T}

Berdasarkan persamaan regresi liniear sederhana yang telah ditampilkan di atas dapatlah dikemukakan untuk menguji pengaruh independen variabel secara parsial digunakan koefisien regresi liniear sederhana untuk independen variabel frekuensi sosialisasi (X). Apabila analisis koefisien ini menunjukkan independen variabel pengaruhnya terhadap dependen variabel tidak signifikan pengaruhnya terhadap variasi penerimaan Pajak Bumi dan Bangunan di Kota Palopo dapat kita lihat pada nilai untuk distribusi $\mathrm{T}_{\text {hitung }}>\mathrm{T}_{\text {tabel }}$
Berdasarkan hasil uji statistik frekuensi sosialisasi (X) pada tabel di atas dapat dilihat dengan $\mathrm{db}$ (derajat bebas) $=1$ dan taraf kepercayaan 95\% $\mathrm{T}_{\text {hitung }}=-1,304$ dengan nilai siqnifikasi 0,233atau 23,3\% jauh lebih besar (X) 0,05 dengan demikian dapat di jelaskan bahwah frekuensi sosialisasi tidah berpengaruh siqnifikan terhadap penerimaan Pajak Bumi dan Bangunan di Kota Palopo.

Penelitian yang dilakukan oleh (Arman,2013) ditemukan bahwa persentase orang yang bersedia pajaknya dinaikkan, bila pelayanan terhadap masyarakat ditingkatkan, jauh lebih besar dari persentase orang yang minta pajaknya diturunkan (Ancok, 2004:1). Gambaran di atas, sekilas terkesan bahwa orang tidak selalu anti dengan pajak. Meski demikian ada pula indikasi semakin berkurangnya toleransi orang pada pajak. Penelitian jangka panjang dilakukan Pemerintah memperlihatkan munculnya kecenderungan orang semakin antipati pada pajak. Di tahun 2004 terdapat $61 \%$ responden Gallup Pool menjawab bahwa pajak yang mereka bayar terlalu tinggi.

Menurut majalah tempo tahun 2004 pernah melakukan penelitian tentang sikap membayar pajak. Dari 991 responden yang diwawancarai, $8,89 \%$ diantaranya menyatakan bahwa mereka, membayar pajak dalam jumlah yang kecil. Hasil survei yang dilakukan di beberapa daerah di Sulawesi Selatan (Pinrang, Sidrap dan Pangkep) menunjukkan bahwa orang tidak selalu mengharapkan pajaknya diturunkan seperti yang sering diduga banyak orang.

Untuk memudahkan penagihan pajak bumi dan bangunan maka perlu pemerintah daerah melaksanakan sosialisasi dengan masyarakat 
karena dengan adanya sosialisasi, maka masyarakat dapat mengetahui bahwa sesungguhnya PBB sangat penting dan sifatnya wajib. Sehingga masyarakat tahu bahwa Pajak Bumi dan Bangunan merupakan pajak yang dikenakan atas harta tak bergerak dalam hal ini yang dipentingkan adalah objeknya maka status atau keadaan orang atau badan yang dijadikan subjek tidak penting dan tidak mempengaruhi besarnya pajak. Karena Frekuensi sosialisasi sangat berpengaruh terhadap penerimaan pajak bumi dan bangunan di Kota Palopo.

\section{SIMPULAN}

1) Berdardasarkan hasil analisis regresi linier sederhana diperoleh nilai sebesar $\mathrm{Y}=0,951$ $+0,774 \mathrm{X}$ hal ini menunjukkan bahwa frekuensi sosialisasi (X) berpengaruh terhadap penerimaan Pajak Bumi dan Bangunan (Y) di Kota Palopo.

2) Nilai R (koefisien korelasi) sebesar 0,947 atau $94,7 \%$, memberikan arti bahwa terdapat hubungan antara independen variabel (frekuensi sosialisasi) dengan dependen variabel (penerimaan Pajak Bumi dan Bangunan) sebesar 0,947 atau 94,7\%, secara kuantitaf memperlihatkan hubungan yang sangat kuat atau mendekati 1 karena memiliki nilai sebesar $94.7 \%$ dengan tingkat kepercayaan 95\% dengan tingkat kesalahan 0,05.

3) Hasil analisis adjusted R Square $=0.619$ memberikan arti bahwa faktor frekuensi sosialisasi (X) mempengaruhi penerimaan Pajak Bumi dan Bangunan Kota Palopo dengan memberikan sumbangan sebesar $61,9 \%$ tergolong tinggi artinya bahwa tinggi rendahnya variasi penerimaan Pajak Bumi dan Bangunan ditentukan oleh ditinggi rendahnya variasi frekuensi sosialisasi (X) di Kota Palopo.

4) Besarnya nilai koefisien regresi adalah 0,774 menunjukkan bahwa jika variabel frekuensi sosialisasi $(\mathrm{X})$ memiliki pengaruh positif terhadap penerimaan Pajak Bumi dan Bangunan Kota Palopo artinya jika skor frekuensi sosialisasi (X) naik 1 satuan maka penerimaan Pajak Bumi dan Bangunan Kota Palopo naik sebesar 0,774 satuan dengan asumsi variabel lainnya berada dalam keadaan konstan.

5) Dari hasil uji statistik frekuensi sosialisasi (X) pada tabel di atas dapat dilihat dengan $\mathrm{db}$ (derajat bebas) $=1$ dan taraf kepercayaan 95\% $\mathrm{T}_{\text {hitung }}=8,404$ sedangkan $\mathrm{t}_{\text {tabel }}$ $=2,920$. Oleh karena $\mathrm{t}$ hitung $>\mathrm{t}$ tabel, maka frekuensi sosialisasi (X) secara individual (parsial) terbukti signifikan berpengaruh terhadap penerimaan Pajak Bumi dan Bangunan di Kota Palopo,

\section{DAFTAR PUSTAKA}

Andi. Prakosa, Kesit Bambang, 2008. Hukum Pajak, Yogyakarta, : Ekonesia

Badan Pusat Statistik, 2007/2008, Kota Palopo Dalam Angka, BPS Kota Palopo.

Brotodihardjo, R . Santoso, 2007, Pengantar Ilmu Hukum Pajak, Bandung, PT Eresco.

Direktorat Jenderal Pajak. 1992, Buku Panduan Pajak Bumi dan Bangunan, Jakarta Selatan, PT Bina Rena Pariwara.

Goedhart, C. 1983, Garis-Garis Besar Keuangan Negara, Terjemahan Ratmoko, Jakarta, Djambatan.

Mardiasmo, 2003, Perpajakan. Edisi Revisi, Yogyakarta. 
Purwanto Suharyadi., 2007, Statistika Untuk Ekonomi dan Keuangan Modern, Jakarta, Salemba Empat.

Ratmoko 2007, Pajak Bumi dan Bangunan, Bandung, PT Eresco.

Santoso, Rokhmat, 2007, Pajak Bumi dan Bangunan, Bandung, PT Eresco.

Sekretaris Negara, 1988, Garis-Garis Besar Haluan Negara, Jakarta.

Soemitro, H. Rochmat, 2007, Pajak Bumi dan Bangunan, Bandung,

PT Eresco.

Suparmoko, M. 2007, Keuangan Negara dalam Teori dan Praktek, Yogyakarta, BPFE.

Suseno Trianto, Hg. 200, Indikator Ekonomi, Yogyakarta:

Sugiarto, 2007, Metode Statistika Bisnis dan Ekonomi, Penerbit PT Gramedia Pustaka Utama, Jakarta.

Soeparmoko, 2007, Pajak, Penerbit Edisi Revisi Yogyakarta,

Kanisius. Undang-Undang Nomor 12 Tahun 1994 tentang Perubahan Undang-Undang Nomor 12 Tahun 1985 tentang Pajak Bumi dan Bangunan.

Sitti Kurian Rahayu 2010 Perpajakan: Konsep, teori, dan isu. PT. Kencana, Jakarta.

Wirawan, 2007. Perpajakan Penerbit Andi Yogyakarta

Wirawan B, Ilyas. 2007. Perpajakan Indonesia. Jakarta: Salemba Empat.

Zain, 2010, Perpajakan, Jakarta: Salemba Empat

Undang-Undang Perpajakan 1994. Bandung: Citra Umbara Bandung

Undang-Undang Nomor 12 Tahun 1985 Tentang Pajak Bumi dan Bangunan telah dikeluarkan beberapa Peraturan
Pemerintah, SK Menteri Keuangan dan SK Direktur Jenderal Pajak 